\begin{tabular}{|l|l|l||}
\hline \multicolumn{2}{|c|}{ PublisherInfo } \\
\hline \hline PublisherName & $:$ & BioMed Central \\
\hline \hline PublisherLocation & $:$ & London \\
\hline \hline PublisherImprintName & $:$ & BioMed Central \\
\hline \hline
\end{tabular}

\title{
Inhibiting carotenoids
}

\begin{tabular}{|l|l|l||}
\hline \multicolumn{2}{|c|}{ ArticleInfo } \\
\hline \hline ArticleID & $:$ & 4344 \\
\hline \hline ArticleDOI & $:$ & $10.1186 /$ gb-2002-3-6-reports0031 \\
\hline \hline ArticleCitationID & $:$ & reports0031 \\
\hline \hline ArticleSequenceNumber & $:$ & 23 \\
\hline \hline ArticleCategory & $:$ & Paper report \\
\hline ArticleFirstPage & $:$ & 1 \\
\hline \hline ArticleLastPage & $:$ & 3 \\
\hline \hline & & RegistrationDate : 2002-4-1 \\
ArticleHistory & $:$ & Received \\
& $:$ 2002-4-1 \\
\hline \hline ArticleCopyright & $:$ & BioMed Central Ltd2002 \\
\hline \hline ArticleGrants & $:$ & \\
\hline \hline
\end{tabular}




\begin{tabular}{|l|l|l||}
\hline ArticleContext & $:$ & 130593366 \\
\hline
\end{tabular}

\section{Wim D'Haeze}

\section{Abstract}

A study of carotenoid synthesis was carried out to discover inhibitors that might provide new herbicides

\section{Significance and context}

Carotenoids - carotenes and xanthophylls - give color to fruits and flowers, and have an important role in photosynthesis, where they participate in light harvesting and protect the photosynthetic apparatus against high light intensities. Carotenoid synthesis involves a phytoene synthase (PSY), a phytoene desaturase (PDS), a $\zeta$-carotene desaturase (ZDS), and lycopene cyclases to form, for instance, $\beta$ - and $\alpha$ carotene, zeaxanthine, violaxanthin, and neoxanthin. The study of carotenoid synthesis in plants is interesting from a nutritional point of view to increase the vitamin A content, and also to discover ways of blocking carotenoid synthesis and thus removing their protective role in photosynthesis. To find appropriate targets for such herbicidal action, Busch et al. focused on the effects on carotenoid synthesis of up- and down-regulating the expression of the genes $p s y$ and $p d s$ from Nicotiana tabacum (tobacco).

\section{Key results}

Using PCR and primers designed against conserved regions within reported similar gene sequences, two copies of $p s y$ and one copy of $p d s$ were isolated from tobacco. The corresponding proteins show about $90 \%$ or more identity to those of described PSY and PDS proteins, respectively. The coding sequences of $p s y 1, p s y 2$, and $p d s$ were expressed in sense and antisense in transgenic tobacco plants, obtained by transformation mediated by Agrobacterium tumefaciens, and the effects on metabolism and phenotype were studied. Some plants overexpressing psyl showed severe phenotypes, including dwarfism, changes in leaf pigmentation, a rolled appearance of the leaves, young leaves that appeared orange-colored, buds that were unable to flower, and flower-color changes. Overexpression of psy2 led to similar but less severe phenotypes in a number of plants. In plantsoverexpressing either psy1 or psy2, changes in carotenoid and chlorophyll content were noticed. In orange capsules that surround the seeds, for instance, the carotenoid content increased up to $400 \%$ and the chlorophyll content decreased to $6 \%$ as compared to green capsules. Antisense $p s y 1$ and $p s y 2$ expression did not show any significant phenotypes in primary transformants. Overexpression of $p d s$ did not cause any phenotypic or metabolic effects, in contrast to plants expressing $p d s$ antisense in which a dramatic accumulation of phytoene was 
noticed together with an increased carotenoid content. Some of the latter plants showed small white spots on their leaves, and white veins and leaf tips were noticed. Antisense expression of $p s y$ and $p d s$ was lethal for a population of transgenic plants.

\section{Links}

The study was performed at Bayer AG and more background information concerning the company can be found at the Bayer AG website.

\section{Reporter's comments}

Busch et al. describe the effects of sense and antisense expression of two genes involved in the synthesis of carotenoids on tobacco phenotype and metabolism. Clearly, both the PSY and PDS enzymes can be used as targets to develop new herbicides, as the correct production of carotenoids seems to be important for tobacco survival. Purification and further characterization of these tobacco enzymes, and the isolation of similar genes from other plants, should be part of future research to reach this goal. The in-depth characterization of these enzymes in a variety of plant genera may also reveal unique features of these enzymes depending on the plant species, which may subsequently be exploited to develop more specific herbicides.

\section{Table of links}

Plant Physiology

Bayer AG

References

1. Busch M, Seuter A, Hain R: Functional analysis of the early steps of carotenoid biosynthesis in tobacco. Plant Physiol. 2002, 128: 439-453. 0032-0889

This PDF file was created after publication. 